\title{
A sociological study of children with albinism at a special school in the Limpopo province
}

\author{
RJ Gaigher, DPhil, University of Venda \\ PM Lund, DPhil, Coventry University, United Kingdom \\ E Makuya, BA Hons, University of Venda
}

\section{Abstract}

This article maintains that it is the social context, as much as, and sometimes more than the physical condition, that largely structures and limits the lives of people with albinism. It deals with albinism from a sociological, rather than a medical perspective. Viewed as such the problems experiencing by affected people stem primarily not from their physical differences but from the way others respond to those differences and from the social and physical environments they have to cope with. The article is based on a study of 32 children with albinism from a special school in the Limpopo province. Educational, health and social problems, attitudes and perceptions about albinism were tested by way of structured interviews. The data reveal an acute lack of information about the causes and consequences of albinism. It projects it as a condition still deeply immersed in myths and superstition resulting in the stigmatising and rejection of affected people. It also discloses a physical environment which is preventing rather than supporting people with albinism from reaching their potential. It calls for a reorientation in dealing with albinism -away from just medical intervention to treating it as a social construct requiring a holistic approach.

\section{Opsomming}

Hierdie artikel redeneer dat dit die sosiale konteks, eerder, en nog meer as die fisiese toestand is wat tot 'n groot mate mense met albinisme se lewens beheer en struktureer. Dit beskryf albinisme vanuit 'n sosiologiese, eerder as 'n mediese verband. As sulks is die probleme van mense met albinisme nie primer ' $n$ verskil in fisiese voorkoms gesetel nie, maar in die wyse waarop ander persone op hierdie verskille reageer en in die sosiale en fisiese omgewing waarbinne hulle moet funksioneer. Die artikel is gebaseer op 'n studie van 32 kinders met albinisme by 'n spesiale skool in die Limpopo provinsie. Gesondheids, leer en sosiale probleme, houdings en persepsies oor albinisme is by wyse van gestruktureerde onderhoude getoets. Betekenisvolle bevindinge sentreer om 'n akute gebrek aan inligting oor die oorsake en gevolge van albinisme met gepaardgaande mites en bygelowe. Die gevolg is stigmatisering, verwerping en diskriminasie van geaffekteerde persone. 'n Verdere bevinding is dat die sosiale en fisiese omgewing waarin persone met albinisme moet funksioneer hulle eerder beperk as ondersteun in die bereiking van persoonlike potensiaal. Dit vereis 'n herorientering in die hantering van albinisme - vanaf ' $n$ oorwegend mediese model na een waarin die toestand as beide 'n fisiese en 'n sosiale konstruksie beskou word en vanuit ' $n$ holistiese benadering hanteer behoort te word.

\section{Introduction}

Oculocutaneous albinism (OCA) is a recessive genetic condition prevalent throughout sub-Saharan Africa. It is characterised by hypopigmentation of the skin, hair and eyes. One form, tryosinase positive OCA (OCA2), is by far the most common type in Southern Africa (Stevens, van Beukering, Jenkins and Ramsay 1995). In indigenous black African populations, OCA2 subjects have sandy coloured hair, pale chalky white skin, often burned by the sun and blue to light brown eyes showing nystagmus (rapid eye movements), photophobia, lack of binocular vision and poor visual acuity. This vulnerable group has an increased risk of developing skin cancer due to the lack of protective melanin. Albinism occurs in every ethnic or population group, but members of black populations are particularly vulnerable because they live mainly in the tropics, which has a devastating impact on their skin.
Their appearance is, in addition, strikingly different from their darkly pigmented peers, resulting in a range of social, psychological and educational problems. The frequency of OCA2 is about 1 in 3900 in South African black populations (Kromberg and Jenkins, 1982). Certain ethnic groups show, however, a higher prevalence as a result of traditional marriage patterns that encourage consanguineous unions.

As the intelligence of those with albinism falls within the normal range (Manganyi, Kromberg and Jenkins, 1974) the children can be accommodated in mainstream education. However in South Africa, and particularly in the Limpopo province [formerly Northern province] they often attend special schools because of their poor eyesight. There is no cure for albinism, but it is a condition that can be managed effectively given appropriate health information and a supportive and non-discriminatory social and physical environment. Lit- 
the is known about the psychological, educational, occupational and social problems experienced by people with albinism in the study area although the condition is prevalent in this area.

The physiological problems of people with albinism can to a certain extent be managed with proper sun protection, regular skin examinations and appropriate eye care. The psychosocial problems though, have deeper roots, are less well understood and more difficult to address. In Africa, people with albinism are often stigmatised and ostracised by society. Misconceptions and myths about albinism abound in Africa, with beliefs as to the cause of the condition ranging from a punishment or a gift from God to conception during menstruation or eating prohibited foods during pregnancy (Kromberg and Jenkins 1984; Okoro, 1975; Kagore and Lund, 1997). In schools these beliefs tend to isolate and stigmatise pupils with this condition, indicating a need for accurate and scientifically based information about the genetic origin of albinism as well as its social, educational and psychological implications (Lund and Gaigher, 2002)

This article maintains that it is the social context, as much as, and sometimes more than the physical condition, that structures and limits the lives of people with albinism. It deals with albinism from a sociological, rather than a medical perspective. Viewed as such the problems experiencing by affected people stem primarily not from their physical differences but from the way others respond to those differences and from the social and physical environments they have to cope with. The sociological model emphasises social forces and public issues rather than individual physical variations and complications. (Weitz, 1996:55). Sociologists reason that our very sense of whom we are and our important social relationships are intimately connected with our bodies. As people with albinism have bodies that cannot always be counted on to function according to the individual's demands, the condition is often disruptive and disordering. While any disorder is disruptive, after recovering, one emerges to retain and reclaim essential relationships and identity. Disorders like albinism from which there is no recovery, threaten the affected person's important relationships and very sense of self.

This article focuses on the experience of albinism as shaped by the physical and social environment as well as through culture. It describes the complex strategies affected people have to design to deal with daily activities and social relationships.

\section{Research design and objectives}

The objective of the study was to explore the social and educational problems of a group of children with albinism attending a school in the Venda region of the Limpopo province. Data was collected through a social survey with an interview schedule as technique. Although the questions were in English, the interviewer was Tshivenda speaking and could translate complicated questions into the local language. The interview schedule included socio-demographic, health, educational and sport information. A section dealing with attitudes and perceptions provided information on how the re- spondents deal with their condition. Thirty two of the 49 affected children attending Tshilidzini Special school were interviewed. The children not included in the sample were those younger than 6 years of age. Consent was obtained from the headmaster to undertake this study and only volunteers took part. One person, an MA student in Sociology, acted as interviewer; each child was interviewed individually. Reliability and validity of individual questions had been established through a pilot study as well as through input from the teachers of children with albinism. In this manner ambiguous or unnecessary questions could be omitted or rectified and potential problems of interpretation and translation prevented. Data were analysed manually and with the help of Excel (a computerised statistical program) for the presentation of tables and graphs. The study was of an exploratory nature, serving as a basis for a future more comprehensive study. The fact that the interviewing took place at the school may have restrained the children from revealing problems experienced at school and biased the findings to a certain degree. In terms of generalisation the study is restricted to this school although the results correspond with findings of similar studies in southem Africa (Lund, 1997; 2001).

\section{Discussion of main findings The subjects}

Fourteen male and 18 female primary school pupils were interviewed. The ages of the respondents ranged from 5 to 18 years. The majority (28) were Tshivenda speaking with 4 Xitonga speaking children originating from 22 different villages. Except for 2 respondents whose fathers were deceased, parents of the rest were still alive and took care of them and the children appeared to have stable family ties. Respondents come from households with an average of 5 children; 13 had at least one sibling with albinism. None of the respondent's grandparents or parents have albinism although, given the genetic pattern of inheritance of OCA, both parents of children with albinism must be carriers of the condition.

\section{Educational issues}

The stigma attached to albinism is usually a source of great anguish and shame to parents and affected individuals (King, Summers, Haefemeyer and Leroy 1996; Lund 1998; Kromberg, Zwane, and Jenkins, 1987). As a result some parents may not send their children to school because of the mistaken belief that children with albinism are retarded, cannot compete favourably with other children and therefore cannot succeed in life. It may consequently happen that some children with albinism do not receive the same encouragement and intellectual stimulation as their unaffected siblings. They are in addition more isolated from activities that stimulate cognitive and perceptual motor development because they cannot take part in all the outdoor activities and tasks. The skills children acquire to perform certain tasks effectively strengthen their self-confidence. Children with albinism, however, often feel threatened when surrounded by healthy children who exuberantly and confidently master new skills and play games from which they are excluded because of poor eyesight or a highly sensitive skin. At school, poor vision, skin problems, social adaptation and lack of an appropriate physical environment impede their progress. Children with 
albinism benefit from special equipment and specially trained teachers to make normal educational progress. In this school, the visually impaired and blind children share the same classroom and teachers, resulting in constant disagreement on issues such as the amount of light needed. Children with albinism are very sensitive to harsh light while other partially sighted children want more light. Some of them are older than most of their peers in corresponding grades in mainstream schools. This impacts negatively on their acceptance by, and integration with, the rest of the community. In this study 2 respondents were 18 years old while still in grade 6 and 7 respectively. They are, nevertheless, possibly more protected and cared for in the special school than they would be in a mainstream school. Despite this, 18 respondents said that they would like to attend a mainstream school while 14 preferred to be at a special school similar to the one they are attending at present.

This preference for mainstream education apparently has more to do with emotional than educational needs. The children with albinism prefer to be in family surroundings attending the same schools as their normally pigmented friends. This is unfortunately not possible, as mainstream schools in this area are much less equipped to accommodate children with disabilities of any kind. Respondents who were not interested in going to a mainstream school were afraid of being rejected or ridiculed by normally pigmented children or felt they would not receive the kind of treatment they are getting at the special school. In rural areas where large sections of the population live in chronic poverty there is very little infrastructure specially designed to deal with such problems.

In terms of emotional needs and the development of self-esteem it would therefore be ideal if children with albinism could be accommodated in mainstream education. It seems that these children have a constant battle with a social desire to be with family and friends and the educational opportunities provided by the special school. In the school they are almost 'forced' to choose friends from amongst disabled children while they are striving to be as 'normal' as possible and associate with normally pigmented peers. Such a situation poses a threat to identity and self-concept. Charmaz (1983) has described how people with some form of physical disability are constantly involved in a struggle to lead valued lives and maintain definitions of self that are positive and worthwhile. This is also true for people with albinism where cultural definitions devalue the individual and negative interactions with others may constantly undermine the individual's sense of self-worth. This 'loss of self' can be a powerful form of suffering experienced by people with albinism. The crucial factor, which has an influence on the manner and extent to which these problems are managed, is the resources to which individuals have access. These resources may take many forms: time, energy, money and social support. Appropriate physical environments, formal services that foster independence rather than exacerbate dependence, knowledge and information are perhaps the most important (Scambler, 1991:86). The concept of resources provides on the one hand a mechanism which links a condition like albinism to that of a handicap, while on the other it draws attention to the unequal distribution of resources in society and the ability/inability of individuals from different socio-economic groups to maintain a satisfactory existence. In this manner the availability of resources links personal concerns with wider social and political issues. This linkage is undoubtedly a valuable analytical tool to explain why people from the $1^{\text {st }}$ world tend not to define albinism as a disability, while people in the developing world, vulnerable and deprived of an environment that enables them to deal with the condition in a successful manner, have no difficulty in describing it as such. Children like those taking part in this study are not so much handicapped by the physical condition of albinism as by an environment not only of chronic poverty but also a lack of educational, health care and physical facilities which would enable them to comply with the demands of society, despite their condition (Ashley and Cates, 1995).

\section{Problems experienced at school}

The majority (20) of the respondents were of the opinion that the problems they were experiencing are more of a social than an educational nature. Eighteen of the 32 children complained about the hostile treatment they receive from deaf children with whom they share a hostel. This often erupts into physical attacks with the children with albinism on the receiving end. A possible explanation for this aggressive behaviour may be that nobody has explained to deaf children (either in writing or in sign language) why the children with albinism look so different from them. This unexplained difference in appearance may frighten them, causing them to attack because of fear rather than aggression. This conflict is only a symptom of a deeper problem experienced by people with albinism; the constant battle to come to terms with a body that does not meet social expectations for role compliance or appearance. It is very difficult to nurture social relationships despite a non-normative body and to construct a viable and life-sustaining sense of self while constantly being rejected by others. A related consequence of being stereotyped as 'different', is that it can confirm individuals in their 'deviant' status, can constrain them to see themselves as others see them and to behave accordingly. This argument, that being treated in the same manner as other children will reduce their feelings of alienation, is being used by proponents of mainstream schooling for children with albinism. This is a valid, provided such schools have special facilities to deal with these children.

Educational problems seem to be subject - specific with half of the children experiencing problems with mathematics. Although most children from deep rural areas in South Africa struggle equally with mathematics, children with albinism must, in addition, deal with poor eye sight which makes it difficult to decipher numbers and figures. The teaching of mathematics is, however, also a problem area in normal schools in rural areas. In special schools lacking properly trained teachers, these problems can be acute, limiting the job opportunities for their pupils even further.

\section{Sport activities}

All respondents (32) took part in some or other form of sport, usually goal ball, a type of team activity that is played indoors. Eleven also played soccer while a further 10 partici- 
pated in other outdoor games. Participating in sport, particularly in team activities, is essential for children with albinism because it provides an atmosphere in which socialization within group dynamics is at its best and very necessary for building identity and self-image. When disorders are not part of life, the relationship between body and self is taken for granted - bodies are suppose to function and sustain a presentation of ourselves as normal, reliable participants in social interaction (Fine and Asch, 1988:14). Facilities that restrict, rather than support equal competition within disparities, leave children with albinism vulnerable because they feel that their bodies become an 'other' - at best an unpredictable ally. Both the school and the villages they come from have very few sport or recreational facilities, with nothing particularly designed for disabled people. With the lack of sporting facilities so reminiscent of third world surroundings in general, such specialised facilities figure somewhere at the bottom of the educational budget. Despite the change in political system in South Africa it is still black and rural families that are the most vulnerable in the face of disparity. People with albinism are no exception.

\section{Occupational preferences}

Asked about occupational preferences, it is evident that people with albinism have the same ambitions as normally pigmented people when it comes to occupational choices. Jobs these children aspired to included health officials, teachers, social workers, police officers, lawyers, professional soccer players, preachers and soldiers. It is a psychological indicator that children with albinism do not want to be seen as a group apart - they want to mix and socialize with other members of the community in an equal manner even by just pretending that their disorder does not make any difference to what they realistically are able to achieve. Rather than letting their disorder overtake their identities, they try to find

\section{Physical and health information}

The majority [28] of respondents rated their health as good. Despite the fact that most [28] of the respondents experienced skin sores and headaches as a result of their eye problems they did not consider these as 'health problems', but almost as 'normal' conditions that do not necessitate special care. Table 1 showing the number of visits to health professionals during the 5 months preceding the survey, supports this assumption.

\section{Number of visits to health professionals}

Visits to a 'nurse' refer to the nurse from the school, while 'clinic' refers to a clinic at home or away from school. The number of visits is relatively low compared to the number of health problems they experienced, including skin sores and poor eyesight. Only one child had visited a clinic four times [almost monthly] while more than half of the respondents had not visited a nurse, doctor, or hospital in that period. The figure is slightly higher for clinic visits, perhaps as a result of parent influence. One would expect that, with nurses at school, the children would make better use of the facilities. Although about half the children had not visited any health official during that period, the other half did get some form of treatment from one of these facilities. Only one child consulted a traditional healer once, while it may be expected that a condition like albinism would motivate particularly uneducated parents, to take them to traditional healers for treatment or explanation of their condition. A possible reason for this may be that the school discourages visits to traditional healers and that children are reluctant to reveal such visits.

A related question revealed that most (24) of the respondents were suffering from skin sores of varying degrees of severity. Despite this, 19 children had never visited any health profes-

Table 1: Number of visits to health professionals

\begin{tabular}{|l|c|c|c|c|c|}
\hline & Once & Twice & Thrice & Four & Never \\
\hline Clinic & 11 & 6 & 5 & 1 & 8 \\
\hline Nurse & 1 & 7 & 9 & 0 & 15 \\
\hline Doctor & 9 & 7 & 1 & 0 & 15 \\
\hline Hospital & 11 & 1 & 3 & 0 & 17 \\
\hline $\begin{array}{l}\text { Traditional } \\
\text { healer }\end{array}$ & 1 & 0 & 0 & 0 & 31 \\
\hline
\end{tabular}

some confined space within their selves and their ambitions to contain it and then draw a boundary around it. In that way their essential selves can be separated from their recalcitrant bodies; the disorder can be made smaller than themselves, their ideals and their dreams (Register, 1987:33) sional to have their skin examined. Seven do, however, visit a doctor for an annual skin examination. Only 5 children go for skin check-ups twice a year while none of them go monthly. If the high prevalence of skin cancer amongst people with albinism is considered (Kromberg, Castle, Zwane and Jenkins, 
1989), it is unfortunate that these children are not examined for early indications of this disease more regularly. As this region is situated in the tropics with very high radiation levels regular check-ups are a necessity. Reasons for the lack of proper health care may be that the nurses at the school do not have time, or the children are not informed about the necessity for such inspections. Although it was not tested in the questionnaire, some of the children also complained about the unfriendly and sometimes rude treatment they received from health officials. This is very unfortunate as these children are already vulnerable and suffer from low self-esteem. Specialised, accessible and people-friendly health care is a necessity for this unique condition.

As illustrated in Fig. 1 respondents were well-informed about the advantages of wearing protective clothing, particularly hats (31) and umbrellas (14). However, only 18 of the 32 respondents said they stay indoors as much as possible, the rest would rather wear hats, long sleeves and trousers to enable them to endure the sun and join their friends. Twenty three applied sunscreen with a sun protection factor, but because it is not regularly supplied by the clinic, many (23) had to rely on ordinary skin creams and lotions which do not provide proper protection. While 22 wore long trousers or dresses with long sleeves, the rest did not, perhaps feeling that such clothing jeopardizes their chances of being accepted by peer groups. People with albinism never tan, they easily get sunburn and sores on exposure to the sun. They have ultra sensitive skins and should avoid the sun as much as possible, particularly around midday (King et al., 1996). It is important for parents, teachers and health care officials to encourage good sun protection behaviour.

Although all the children suffer from ocular problems including photophobia, nystagmus, a lack of binocular vision and reduced visual acuity, only 14 had been for an eye test. Of the 5 who wore spectacles only one used tinted glasses. Those who have spectacles but do not wear them said they caused headaches, perhaps due to an incorrect optical prescription. Due to their many eye problems it is often difficult to obtain the best optical correction of those eye problems that can be corrected, such as refractive errors.

Figure 1 : Protective Measures

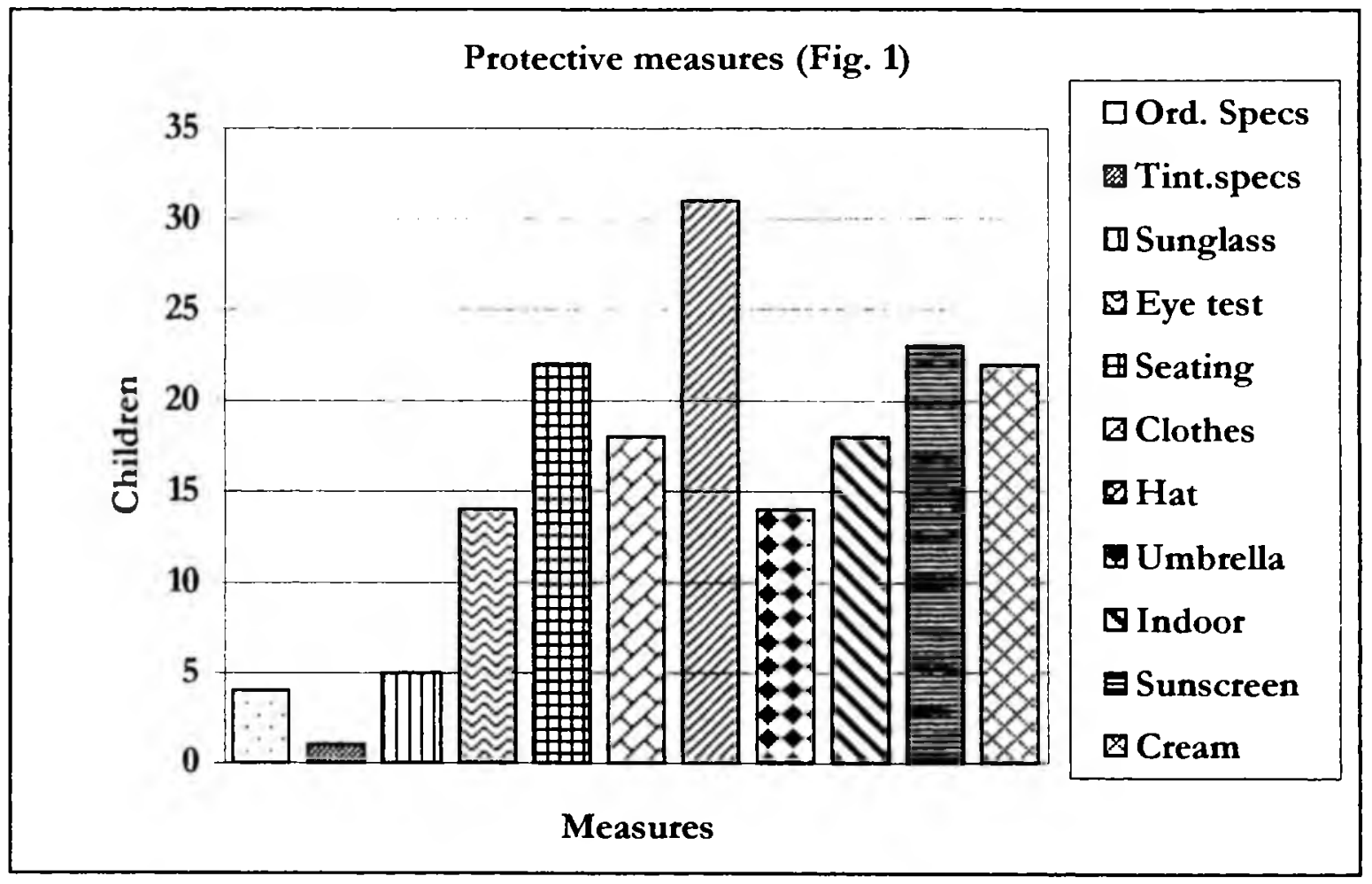




\section{Perceptions about albinism}

None of the respondents had received any explanation about the causes or consequences of albinism from teachers, relatives or health officials. Although the causes for albinism need complex genetic explanations, children only need to be given very basic physiological explanations. What they need above all is psychological assurance that they are not the products of some mysterious and evil supernatural forces, that their parents have done nothing wrong and that they have the same rights as their unaffected relatives. All of these respondent's parents have normally pigmented black skins, which isolates the child with visible albinism even more. Some parents can develop resentment against the child, as if the child is responsible for being so strikingly different from the rest of the family (Kromberg et al., 1987:913)

While most of the respondents knew that albinism is not contagious, 7 were not certain. The fact that most people with albinism know that the condition is not contagious, because they have never infected another person, does not mean that it is such an obvious deduction in the community. A later question revealed that people were still afraid to touch or sit next to people with albinism, or to touch something they have handled for fear of getting infected or, in some way, affected. These are very painful experiences for small children who need physical expressions of love and care and for teenagers who are looking for group interaction and acceptance. Kromberg et al. (1987) describe how even mothers of children with albinism are reluctant to hold and breast-feed their new-born babies. A community better informed about albinism may be able to accommodate people with this condition in a less prejudiced and more facilitating manner.

Most (23) of the respondents also knew that albinism cannot be cured although 9 respondents were not sure. Twenty respondents indicated that people with albinism do not have a shorter life span compared with people without albinism, although 12 were undecided.

Asked about intelligence, 17 respondents were positive that people with albinism are just as intelligent as normally pigmented people. A single respondent rated people with albinism as less intelligent while 14 were undecided. Studies by Beckham (1946) and Stewart and Keeler (1965) found no significant difference in the intelligence scores of people with and without albinism. Ezeilo (1989:1129) also argues that if people with albinism do not reach the height of their nonaffected counterparts, then non-intellectual factors need to be considered. This coincides with the responses of children in this study who were not convinced that being equal in intellectual abilities would provide them with the same chance of success in life. Thirteen respondents thought that only a few people with albinism could be equally successful, while only 4 gave them an equal chance of success. first time. This included rude treatment, name calling ('muxwete' in Tshivenda), fear, mostly from young children, as well as avoidance, rejection and disregard. When asked about the possibility of a future marriage and marriage partner, most wanted to marry a partner without albinism. Nine preferred a partner with albinism while 2 did not want to marry. Reasons provided for marrying a partner with albinism ranged from expectations of unfair treatment by normally pigmented partners or their families, better acceptance by partners with albinism or a belief that no one without albinism would love and marry them. Preference for partners without albinism resulted from fear that a partner with albinism would exacerbate the problem as well as doubt about whether they would be able to support a family, as both would have difficulty in securing jobs. Their first choice was to marry someone without albinism but if they did not have a choice they would marry someone with the same condition.

The reasons provided for not wanting to marry a partner with albinism did not include the most obvious of all, namely the genetic one of the possibility of producing children with the same condition. If both parents have the same type of albinism then all their children will also be affected. It is obvious that the respondents have little knowledge of albinism as an inherited condition and of the implications for marriage. In the case of this specific sample, the children could also not draw a logical correlation between their parents or grandparents having albinism and their own condition; as the data showed them all as normally pigmented, although several had siblings with albinism.

The choice of a marriage partner is a serious dilemma for people with albinism. Stigmatised and prejudiced by their condition, their chances of marrying a normally pigmented person is severely reduced. Marrying a person with albinism means they will have off- spring with the same condition and duplicates the obstacles in securing an acceptable socio-economic environment. It also increases their isolation and problems of social integration. Another unhappy consequence of being labeled as socially unacceptable is that people's stigma can come to dominate the perceptions that others have of them and how they treat them. In the vocabulary of sociology, an individual's 'deviant' status becomes a master status. Whatever else he or she may be - for example teacher, student or mother - he or she is regarded primarily as a victim of the condition (Scambler, 1991:187). In Ezeilo's study one subject described this experience as: 'one reference to his physical state will shatter all the man and fight in him' (Ezeilo, 1989:1130). Women with albinism are in a particularly vulnerable position. As they do not meet social norms of sexual attractiveness, others may assume that they do not have any sexual feelings at all. Such a denial of women's sexuality can significantly limits their quality of life and self-image (Lonsdale, 1990). At the other extreme, a woman with albinism could be sexually exploited as a result of curiosity rather than being treated affectionately (Ezeilo, 1989:1130).

Nearly all (31) respondents indicated that their parents or guardians as well as siblings treated them similarly to the rest of the family. Taken into consideration their poor eyesight and extreme sensitivity to the sun and artificial lights,
All the respondents had experienced negative behaviour from the community particularly when they meet someone for the 
similar treatment is unlikely. This type of response is again indicative of these children's desire not to be seen as different - to create an image for themselves in the manner they would like others to perceive them.

\section{Myths and beliefs about albinism}

Myths and beliefs about albinism abound in Africa. Apart from those discussed in the introduction,

there is also a myth that those with albinism do not die naturally but simply vanish or disappear (Kromberg, 1992). Apart from 2 who mentioned this belief, the children in this study were not aware of any other beliefs. It is however doubtful if this is the case because at the university near this school, students with albinism are well acquainted with other myths. They may also be denying it for fear of being seen as ignorant or superstitious or feel they will be protected from it if they feign ignorance. However, as these children grow up they will have to face the fact that myths and beliefs are at the basis of cultural stereotyping. However far-fetched or misleading such stereotyping may be, the affected person cannot ignore how others expect them to behave; to do so might well be to ignore key factors in interacting with them. Stereotyping and stigmatization vary in terms of their visibility and obtrusiveness and the extent to which they are recognised. Not surprisingly, there is an equivalent degree of variation in their effects on individuals' lives. People who are 'discredited', to use Goffman's (1963) terminology, are those whose stigma is immediately apparent, such as people with albinism. In order to deal with this stigma, affected people are constantly trying to manage tension. This tension is brought about by the fact that the affected person is trying to be accepted by strangers (usually on the basis of the stereotype), then to break through the stereotype and be accepted as "normal' and eventually to sustain this definition of themselves as being 'normal' (Scambler, 1991:189). People with albinism who have bodies that differ in a critical manner from the norm, must develop a self-concept in the context of a culture that interprets bodily differences as signs of moral as well as physical inferiority (Weitz,1996:178). In an African cultural context it can also be attributed to evil forces and wrong-doing. The resulting stigma leads individuals to feel set apart from others.

Getting rid of this stigma poses serious problems to people with albinism. In order to act 'normal' should they sit at the back of the class pretending that they can see as well as the rest? Do they take part in sport activities that keep then in the sun to such an extent that they develop skin cancer? The need to wear protective clothing seriously increases their tension in deciding how far to compromise to fit in with peer group fashions. It is therefore not surprising that almost all the respondents were of the opinion that fair and equal treatment by the society is the aspect most needed to improve the lives of people with albinism. They can deal with their physical condition, provided they have a supportive society that allows them to do so. Unfortunately none of the children belong to any support group or an organisation for people with albinism. An albinism society can help to demystify unfounded myths and beliefs as well as wrong perceptions, attitudes and behaviour. It can in addition serve as a support system for people with albinism, their families, teachers, health professionals and the community.

\section{Conclusion and recommendations}

Both as a social construct and a social status, albinism affects all aspects of individual lives. In addition to managing the physical condition, albinism affects relationships with family and friends, work and educational performance, opportunities and perhaps most importantly, one's sense of self and relationship with one's own body. When these conditions occur simultaneously with the social disadvantages experienced by people who are traditionally recognized as minority groups, the situation becomes acute. People with albinism belonging to the black population in South Africa fall within this category. Having to cope with their own stress and anger within society's negative attitude, they must also do so in the absence of a physical environment that allows them to reach their potential.

Based on the findings, social intervention programs should consider the physical as well as social and psychological wellbeing of people with albinism. How the individual copes with his/her condition depends mostly on the family environment and the socialization process. If rejection starts from birth, the chances are high that people with albinism will later succumb to society's negative attitudes and stereotyping. In this regard information, advice and support are amongst the most important interventions, their goal being to help the person with albinism to live as normal and satisfying a life as possible within family and community. Informed parents, teachers and health officials can help the children to explore new and positive ways of responding to teasing, rejection and other forms of discrimination. An albinism society for this area will be particularly effective in reaching these objectives. The contribution of specially trained genetic nurses will also be invaluable, as they can provide support as soon as a baby with albinism is born. On a more macro level, government agencies should provide a physical environment able to support, rather than restrict people with albinism, allowing them to develop their talents. Special schools dealing with children with albinism need to have the necessary facilities and specially trained teachers to deal with both the physical and psychological effects of albinism. Working as a team and treating people as a whole, we can find ways and means for children with albinism to reach their potential, to develop a positive self-image within a supporting social environment. Studies like these can contribute to a better understanding of people with albinism and provide a theoretical base from which such social intervention programs can be planned and implemented.

\section{References}

ASHLEY, J \& CATES, D 1995: Educational Techniques for Parents and Teachers with children with Albinism. Review. 24(3): 127. 
BECKHAM, A 1946: Albinism in negro children. Journal of Genetic Psvchology. 69:199-215.

CHARMAZ, $K$ 1983: 'Loss of self: A fundamental form of suffering in the chronically ill. Sociology of Health and IIIness. 5:168-195.

EZEILO, B 1989: Psychological aspects of albinism: an exploratory study with Nigerian (Igbo) albino subjects. Social Science and Medicine. 9:1129-1131.

FINE, M \& ASCH, A 1988: Disability beyond stigma: Social interaction, discrimination and activism.. Journal of Social Issues. 44: 3-21.

GOFFMAN, E 1963: Stigma: Notes on the management of spoiled identity. Englewood Cliffs: Prentice-Hall.

KAGORE, F \& LUND, P 1995: Oculocutaneous Albinism among School Children in Harare, Zimbabwe. Journal of Medical Genetics. 32:859-861.

\section{KING, R; SUMMERS, C; HAEFEMEYER, J \& LEROY,} B 1996: Facts about Albinism and Hypopigmentation. University of Minnesota, USA. National Albinism Organisation. Kromberg, J \& Jenkins, T 1982: Prevalence of albinism in the South African Negro. South African Medical Journal. 61: $383-386$

KROMBERG, J \& JENKINS, T 1984: Albinism in the South African Negro, III. Genetic counseling issues. Journal of Biosocial Science. 16:99-108.

KROMBERG, J; ZWANE, E \& JENKINS, T 1987: The response of black mothers to the birth of an albino infant. American Journal of Diseases of Children. 141: 911-915.

KROMBERG, J; CASTLE, D; ZWANE, E \& JENKINS, T 1989: Albinism and Skin Cancer in southern Africa. Journal of Clinical Genetics. 36:43-52.

KROMBERG, J 1992: Albinism in the South African Negro: Attitudes and the death myth.. Journal of Birth Defects. 28:159-166.

LONSDALE, S 1990: Women and disability. Basingstoke: Macmillian.

LUND, $P$ 1997: Distribution and education of pupils with albinism in Zimbabwe. Transactions of the Zimbabwe Scientific Association. 71:9-13.

LUND, P 1998: Living with Albinism : A study of affected adults in Zimbabwe. Journal of Social Biology and Human Affairs. 63: 3-10.

LUND, P 2001: Health and education of children with albinism in Zimbabwe. Health Education Research: Theorv and Practice. 16(1):1-7.

LUND, P \& GAIGHER, $R$ 2002: A health intervention program for children with albinism in South Africa. Health Education Research: 13(3):365-372
MANGANYI, N; KROMBERG, J; \& JENKINS, T 1974: Studies of albinism in the South African Negro. I: Intellectual maturity and body image differentiation. Journal of Biosocial Science. 6:107-112.

OKORO, A 1975: Albinism in Nigeria. British Journal of Dermatology. 92:485-492.

REGISTER, C 1987: Living with chronic illness: Days of patience and passion. New York: Free Press.

SCAMBLER, G ED 1991: Sociology as applied to medicine. London: Mackays.

STEVENS, G; VAN BEUKERING, J; JENKINS, T \& RAMSAY, $M$ 1995: An intragenic deletion of the $P$ gene in the common mutation causing tyrosinase-positive oculocutaneous albinism (OCA2) in southern African Negroids. American Journal of Human Genetics. 56:586-591.

STEWART, H \& KEELER, C 1965: A comparison of the intelligence and personality of moon child albino and control Cuna Indians. Journal of Genetic Psvchology. 106: 319-324.

WEITZ, R 1996: The sociology of health, illness and health care. A critical approach. Belmont. Wadsworth. 